\title{
CONTRATO DE TRABALHO INTERMITENTE: OS IMPACTOS DA REGULAMENTAÇÃO NOS DIREITOS TRABALHISTAS*
}

\author{
Caroline Porsche de Menezes** \\ Almiro Eduardo de Almeida**
}

\section{RESUMO}

A Reforma Trabalhista, instituída pela Lei no 13.467 de 2017, dentre diversas alterações à Consolidação das Leis do Trabalho, introduziu ao cenário brasileiro o contrato de trabalho intermitente que consiste na prestação de serviços com alternância de períodos de trabalho e de inatividade, sem prejuízo ao caráter empregatício da relação. Frente a inovação proposta pelo legislador, o presente artigo acadêmico visou averiguar o tratamento justrabalhista outorgado ao contrato de trabalho intermitente, sob a luz da principiologia constitucional e dos preceitos fundamentais do Direito do Trabalho. Por meio da análise aos fundamentos e objetivos elencados pelo legislador, esta pesquisa científica abordou o aspecto econômico da contratação intermitente, a fim de sugestionar os possíveis impactos da regulamentação na economia brasileira. 0 estudo, buscou, por fim, compreender de que forma a inovação trabalhista, se

* Trabalho de Conclusão de Curso apresentando ao Curso de Direito do Centro Universitário Metodista - IPA, na área de concentração do Direito do Trabalho como requisito parcial para obtenção do grau de Bacharel em Direito.

** Graduanda do Curso de Bacharelado em Direito do Centro Universitário Metodista - IPA.

*** Orientador do artigo, Mestre em Direitos Sociais e Políticas Públicas pela Universidade de Santa Cruz do Sul - UNISC, Doutor em Direito do Trabalho pela Universidade de São Paulo - USP e Professor do Curso de Bacharelado em Direito do Centro Universitário Metodista - IPA. 
adotada pelos exploradores de mão de obra, poderá afetar os direitos garantidos aos trabalhadores.

Palavra-chave: Trabalho intermitente. Contrato de trabalho. Princípios trabalhistas. Reforma trabalhista. Lei no 13.467/2017.

\section{INTERMITTENT JOB CONTRACT: THE IMPACT OF REGULATION ON LABOR RIGHTS}

\section{ABSTRACT}

The Labor Reform, instituted by Law No. 13,467 of 2017, among the several amendments to the Consolidation of Labor Laws, introduced to the brazilian scenario the intermittent labor contract consisting of the provision of services that occurs with alternation of periods of working and inactivity, without loss to the employment status. In view of the innovation proposed by the legislator, the present academic article aimed to ascertain the labor treatment granted to the intermittent labor contract, taking notice of constitutional principles and fundamental precepts of Labor Law. By analyzing the foundations and objectives set forth by the legislator, this scientific research addressed the economic aspect of intermittent hiring, in order to suggest the possible impacts of regulation on the Brazilian economy. The study searched to understand how labor innovation, if adopted by labor exploiters, could affect the rights guaranteed to workers.

Keyword: Intermittent job. Labor contract. Labor law principles. Labor reform. Law 13.467/2017.

\section{INTRODUÇÃO}

Opus artificem probat ${ }^{1}$. A partir desse antigo provérbio latino é possível entender a magnitude do Direito do Trabalho para o ordenamento jurídico de uma comunidade. As sociedades capitalistas são baseadas nas relações entre o trabalhador e o proprietário dos meios de produção e o ramo do direito responsável por regular essas interações é o Direito do Trabalho, que busca dar proteção à parte mais vulnerável - o obreiro -, a fim promover justiça social e evitar a exploração por parte da minoria detentora do capital produtivo. Ressalta-se que as inter-relações laborais

10 trabalho é que faz o homem. Provérbio latino. 
acompanham - desde a sua origem na revolução industrial europeia até a revolução tecnológica vista nos tempos atuais - o modelo de produção vigente à época, razão pela qual o Direito do Trabalho se molda a fim de acompanhar as mudanças sociais, dando razão a sua existência.

A presente pesquisa analisará os impactos gerados pela regulamentação do contrato de trabalho intermitente aos direitos dos trabalhadores, tema ainda pouco explorado pela doutrina, visto ser fruto da reforma trabalhista aprovada no segundo semestre de 2017, pela Lei no 13.467 .

Além de inovar no ordenamento jurídico brasileiro, a regulamentação sobre o trabalho intermitente é objeto de debate entre os doutrinadores e aplicadores do direito trabalhista. De um lado estão aqueles que a defendem, justificando que a modernização da legislação trabalhista brasileira - considerando que o cerne desta já completa 75 anos - é fundamental para assegurar o pleno emprego na economia.

Do outro lado, estão aqueles que são contrários à inauguração do contrato de trabalho intermitente, afirmando que sua adoção não aumentará os índices de empregabilidade do país, mas apenas precarizará as relações de trabalho, aumentando os índices de subempregos. Os críticos à inovação legislativa não apenas acreditam na proliferação dos subempregos, como também esperam a precarização dos direitos dos empregados que podem ter seus contratos de trabalho por prazo indeterminado substituídos pela nova forma de contratação. Há, ainda, os que consideram o instituto do trabalho intermitente ilegítimo, tendo em vista que o texto da reforma suprimiu direitos trabalhistas e garantias constitucionais, conquistados durante décadas de lutas dos trabalhadores, sem o devido debate com a sociedade e com os hermeneutas das normas trabalhistas.

Diante de tamanha controvérsia, o presente artigo trabalhará a compatibilidade dos argumentos defendidos pelas duas corren- 
tes ideológicas com os princípios constitucionais e trabalhistas, em destaque para a dignidade da pessoa humana e proteção ao trabalho. Analisar-se-á o texto normativo a fim de compreender o tratamento concedido por esta espécie de contratação às verbas trabalhistas, levantando alguns questionamentos acerca do tema. Por fim, o texto tratará dos prováveis impactos da adoção do contrato de trabalho intermitente no Brasil, sob a perspectiva econômica, examinando as justificativas utilizadas para regulamentação dessa modalidade de contrato.

\section{CONTRATO DE TRABALHO INTERMITENTE À LUZ DA PRINCIPIOLOGIA}

\subsection{PRINCÍPIOS CONSTITUCIONAIS E O DIREITO AO TEMPO DO TRABALHADOR}

O Direito do Trabalho como instrumento de garantias aos trabalhadores, sujeitos de direito e destinatários das normas jurídicas, visa garantir o equilíbrio na relação entre o trabalhador e o detentor dos meios de produção, agindo como limitador do sistema capitalista de produçãón . Para Nelson, o Direito do Trabalho, como ramo autônomo - desvinculado à economia -, foi constituído para que o trabalhador deixasse de ser visto como mercadoria e fosse protegido pelas normas trabalhistas, equalizando a relação de trabalho ${ }^{3}$.

A Constituição da República Federativa do Brasil de 19884, dando respaldo à tutela jurídica almejada pelo Direito do Trabalho, trouxe em seu corpo diversos direitos fundamentais garan-

2 ALMEIDA, Almiro Eduardo de; SEVERO, Valdete Souto. Direito do Trabalho: Avesso da precarização. São Paulo: LTr, 2014.

3 NELSON, Rocco Antônio Rangel Rosso. Da flexibilização das relações de trabalho e a consequente violação do mínimo existencial do trabalhador. Revista Espaço Acadêmico, Maringá, v. 17, n. 200, p. 26-36, jan. 2018.

4 BRASIL. Constituição da república federativa do Brasil de 1988. Diário Oficial da União, Brasília, 1988. 
tidos à classe trabalhadora, tais como a valorização do trabalho, justiça social e a dignidade da pessoa humana. Delgado ensina que a Carta Magna reconhece a atividade laborativa como um dos elementos mais significativos para afirmação do ser humano, tanto no plano individual quanto no plano social e familiar ${ }^{5}$.

Freud, segundo Almeida e Severo, sustentava que o ser humano é estruturado por dois pilares: o erótico (que diz respeito às relações de afeto e à personalidade) e o campo social (que tem o trabalho em seu centro), sendo ambos relevantes para a construção da identidade emocional e psíquica do indivíduo, revelando a significância social do trabalho, pois é a partir dele, também, que o sujeito se reconhece ${ }^{6}$.

Daí, se depreende a nítida importância de se compreender o trabalhador - fornecedor da mão de obra - como sujeito de direitos a quem as normas trabalhistas e constitucionais se dedicam. A Organização Internacional do Trabalho já havia afastado a ideia de que trabalho é mercadoria em 1919, sendo corroborada pela Declaração Universal dos Direitos Humanos, em 1948, que propunha a dignidade da pessoa humana sob o viés do trabalho, como explicitado em seu artigo 23, item 3:

Todo ser humano que trabalhe tem direito a uma remuneração justa e satisfatória, que lhe assegure, assim como à sua família, uma existência compatível com a dignidade humana, e a que se acrescentarão, se necessário, outros meios de proteção social. $^{7}$

5 DELGADO, Maurício Godinho. Direitos fundamentais na relação de trabalho. Revista de Direitos e Garantias Fundamentais, [s.l.], n. 2, p.11-40, 13 ago. 2007, p. 15.

6 ALMEIDA, Almiro Eduardo de; SEVERO, Valdete Souto. Direito do Trabalho: Avesso da precarização. São Paulo: LTr, 2014. p.11.

7 ORGANIZAÇÃO DAS NAÇÕES UNIDAS (ONU). Declaração Universal dos Direitos Humanos. Assembleia Geral das Nações Unidas em Paris. 10 dez. 1948. 
Em resposta às precárias condições de trabalho e os movimentos grevistas e revolucionários do século XIX, o Direito do Trabalho brasileiro, respaldado nas declarações internacionais, regulou as relações trabalhistas, suprindo a urgente necessidade de regulamentação das prestações de serviços, até então abusivas.

A Constituição Cidadã, ápice das garantias sociais, objetivando limitar os abusos de poder do detentor dos meios de produção e, alinhando-se ao ideal de direitos fundamentais, implantou em seu texto diversos direitos trabalhistas, assegurados na relação de trabalho, provendo ao proletariado uma série de garantias das quais se poderá valer, a fim de defender a sua inserção digna no mercado de trabalho, superando - ou ao menos amenizando a concepção de que trabalho é sinônimo de tormento, fazendo com que os trabalhadores enxerguem sua relevância ao sistema. Nesse diapasão, a relação de emprego promove, basicamente, a incorporação do trabalhador na relação contratual e no mercado de trabalho de forma digna e justa ${ }^{8}$, de forma que falar em relação de emprego é, portanto, falar em princípio da dignidade.

A reforma trabalhista, instituída pela Lei no 13.467/2017, aprovada no governo Temer, dentre diversas modificações, implementou o contrato de trabalho intermitente no direito trabalhista brasileiro, sob a justificativa de ser imperiosa e urgente a modernização da legislação. 0 Projeto sancionado pelo Poder Legislativo, em tempos de grave crise econômica e acentuado desemprego, argumentava que a legislação trabalhista era ultrapassada - pois consolidada em 1943 - havendo a necessidade de instauração de um contrato atípico que gerasse novos postos de trabalho, facilitando o ingresso no mercado dos mais jovens e diminuindo os índices de desemprego no país, além de regularizar relações de trabalho informais ${ }^{9}$.

$8 \quad$ BRASIL. Tribunal Superior do Trabalho. 70 anos CLT. Brasília, [2013].

9 SEVERO, Valdete Souto. Contrato de trabalho e trabalho intermitente. In: SEVERO, Valdete Souto et al. Comentário à Lei 13.467/17: contribuições para um enfrentamento crítico. Porto Alegre: HS Editora, 2017, p. 72-77. 
O contrato de trabalho intermitente foi regulamentado pela reforma trabalhista por meio da inclusão do parágrafo terceiro do artigo 443 da Consolidação das Leis do Trabalho ${ }^{10}$ :

$\S 3$ 을 Considera-se como intermitente o contrato de trabalho no qual a prestação de serviços, com subordinação, não é contínua, ocorrendo com alternância de períodos de prestação de serviços e de inatividade, determinados em horas, dias ou meses, independentemente do tipo de atividade do empregado e do empregador, exceto para os aeronautas, regidos por legislação própria.

Trata-se, portanto, de uma nova modalidade de contratação do trabalhador, em que a prestação do serviço, embora subordinada, onerosa e pessoal, ocorre de forma descontinuada, alternando entre períodos de trabalho e de inatividade, na qual o empregador apenas solicita a prestação do serviço quando lhe for necessária e conveniente.

Todavia, a intermitência da relação de trabalho não foi bem recepcionada, trazendo consigo diversas controvérsias, e vem sofrendo duras críticas pela doutrina, em especial no que tange o desrespeito aos princípios constitucionais.

Cruz aponta a intermitência do contrato de trabalho como uma perversa precarização das condições, até então, asseguradas ao trabalhador, pois o impede de planejar seu futuro e de investir no seu presente. 0 indivíduo que labora em circunstâncias incertas, sem saber quando irá trabalhar e quanto receberá no fim de cada mês, é levado ao esgotamento emocional, porque se torna muito mais vulnerável e impotente frente ao seu empregador, não tendo qualquer garantia de trabalho ou de remuneração. Tamanha insegurança submete o trabalhador a condições indignas de

BRASIL. Decreto-lei no 5.452, de 01 de maio de 1943. Diário Oficial da

União, Rio de Janeiro, 01 maio 1943. 
trabalho ${ }^{11}$, em que não tem reconhecido o valor da sua atividade profissional, inibindo sua afirmação como ser social.

A importância do contrato de trabalho fixo e contínuo é destacada por Nogueira, não apenas para o trabalhador, como para a empresa tomadora dos serviços. Do ponto de vista do empregador, a continuidade da atividade laboral impacta diretamente na qualidade e produtividade do serviço prestado, pois o indivíduo que trabalha na empresa, perenemente, está a par do seu cotidiano e se adapta com mais facilidade às eventuais inovações implantadas pelo empregador quanto à produção de bens e serviços, pois está em constante aprendizado. Gize-se, inclusive, que as atividades empresariais atuais, envoltas por constantes inovações decorrentes da era tecnológica, demandam empregados conhecedores das modificações do processo produtivo. Outrossim, o empregado que possui um emprego fixo tem maiores chances de investir na sua profissionalização, tornando-se um empregado mais competente, pois acredita na construção de uma carreira e tem maior e melhor gestão do seu tempo, possibilitada pela continuidade e segurança da relação de emprego ${ }^{12}$.

Plá Rodriguez instrui sobre os benefícios da permanência do contrato de trabalho, no seguinte sentido:

É indubitável que, mesmo estabelecido em benefício exclusivo do trabalhador, o maior prolongamento da permanência deste na empresa redunda também em benefício do empregador. Não somente pela condição psíquica do trabalhador, mas tam-

11 CRUZ, Juliana. Contrato de Trabalho Intermitente. In: GUIMARÃES, Ricardo Pereira de Freitas; MARTINEZ, Luciano. Desafios da reforma trabalhista: De acordo com a MP 808/2017 e com a Lei 13.509/2017. São Paulo: Revistas dos Tribunais, 2017. Cap. 9. p. 153.

12 NOGUEIRA, Eliana dos Santos Alves. O contrato de trabalho intermitente na reforma trabalhista: contraponto com o modelo italiano. In: ESCOLA JUDICIAL DO TRT 15 (Campinas). Revista do Tribunal Regional do Trabalho da 15 a Região. 51. ed. Campinas: Escola Judicial do TRT 15, 2017. p. $127-148$. 
bém pela maior experiência e conhecimentos que se adquirem com o transcurso dos anos e que, definitivamente, beneficiam os empregadores. Há que se acrescentar ainda a vantagem que significa o fato de não estar experimentando e ensinando novos trabalhadores, com a sequela inevitável de erros, fracassos, prejuízos e perdas de tempo. ${ }^{13}$

Sob o viés do trabalhador, Nogueira ressalta que o contrato de trabalho intermitente não se mostra benéfico por prejudicar significativamente a administração do seu próprio tempo. A intermitência do serviço cria um "limbo temporal" ${ }^{14}$ na vida do obreiro, visto que inviabiliza que o tempo destinado à espera pela convocação do empregador seja livremente despendido em projetos pessoais - lazer, cultura, viagens -, bem como dificulta o investimento na sua formação intelectual e na realização de cursos profissionalizantes, tendo em vista que são atividades que ocorrem em horários pré-fixados e o empregado não sabe quando será convocado ao trabalho.

A impossibilidade do empregado administrar o seu próprio tempo decorre da dependência financeira gerada pelo sistema capitalista de produção, haja vista que o empregado depende da convocação para o trabalho para ser remunerado e garantir a sua subsistência e de sua família, de modo que se empenhará para estar sempre disponível quando for requisitado pelo empregador, uma vez que só perceberá salário pelas horas efetivamente trabalhadas e visa ser novamente convocado pelo empregador, no intuito de garantir a continuidade da relação de emprego. Nesse sentido, esclarece Nogueira:

13 RODRIGUEZ, Américo Plá. Princípios de Direito do Trabalho. São Paulo: LTr, 1993, p. 141.

14 NOGUEIRA, Eliana dos Santos Alves. O contrato de trabalho intermitente na reforma trabalhista: contraponto com o modelo italiano. In: ESCOLA JUDICIAL DO TRT 15 (Campinas). Revista do Tribunal Regional do Trabalho da 15 a Região. 51. ed. Campinas: Escola Judicial do TRT 15, 2017. p. $127-148$. 
[...] o trabalhador ficaria à mercê do empregador quanto à gestão de seu tempo de trabalho e arriscaria, acima de tudo, viver em uma situação de espera permanente com obrigação moral de resposta (natural para o empregado subordinado), tornando inconciliável sua vida pessoal e sua vida profissional, aliada à absoluta imprevisibilidade de ganhos para sustento próprio e de sua família. ${ }^{15}$

A incerteza à qual o empregado intermitente é submetido, decorrente da espécie de contrato, ocasiona o retorno da ideia de que o proletariado é mercadoria. Cruz salienta que a instabilidade da prestação laboral atinge diretamente o tempo livre do trabalhador, bem como a sua remuneração, deixando-o vulnerável às condições do detentor do capital produtivo. Tal vulnerabilidade sujeita o empregado à condição de subemprego, impedindo-o que faça um planejamento financeiro de longo prazo, como comprar uma casa, adquirir um veículo ou investir na educação dos filhos. A doutrinadora também afirma que a intermitência do serviço pode elevar os índices de acidente laborais, porquanto o trabalhador não estará habituado com o local de trabalho, tampouco com os possíveis riscos que ele possa oferecer ${ }^{16}$.

Maeda, do mesmo modo, trata o trabalho intermitente como uma violação ao princípio da dignidade da pessoa humana, pois coloca o trabalhador na condição de mero objeto, retrocedendo ao século XVIII ${ }^{17}$. 0 empregado gerenciar a própria vida e ter

15 NOGUEIRA, Eliana dos Santos Alves. O contrato de trabalho intermitente na reforma trabalhista: contraponto com o modelo italiano. In: ESCOLA JUDICIAL DO TRT 15 (Campinas). Revista do Tribunal Regional do Trabalho da 15a Região. 51. ed. Campinas: Escola Judicial do TRT 15, 2017. p. 145-146.

16 CRUZ, Juliana. Contrato de Trabalho Intermitente. In: GUIMARÃES, Ricardo Pereira de Freitas; MARTINEZ, Luciano. Desafios da reforma trabalhista: De acordo com a MP 808/2017 e com a Lei 13.509/2017. São Paulo: Revistas dos Tribunais, 2017. Cap. 9. p. 153.

17 MAEDA, Patrícia. Contrato de trabalho Intermitente. In: MAIOR, Jorge Luiz Souto; SEVERO, Valdete Souto (Org.). Resistência: Aportes teóricos contra o retrocesso trabalhista. São Paulo: Expressão Popular, 2017. Cap. 27. p. 323. 
previsão da sua atividade laborativa são premissas básicas para garantir segurança ao obreiro, o qual deve ser visto como sujeito de direitos e não como uma máquina à disposição da atividade econômica empresarial. Afirma a autora que o empregado não pode viver a espera de um chamado do empregador, pois possui direito à desconexão, a fim de que possa dispor de seu tempo e vivê-lo livremente, sem aguardar o trabalho ininterruptamente.

Esclarece Souto Maior que o empregado não é apenas uma mão de obra ou força de trabalho, mas um cidadão que possui vida além da profissional, razão pela qual as legislações trabalhista e constitucional impõem limitação da jornada de trabalho, na qual se contabiliza o tempo em que o empregado se encontra à disposição do empregador ${ }^{18}$. Assim, a contratação do trabalho intermitente se mostra incompatível com a determinação do artigo 4 o da Consolidação da Leis do Trabalho, pois desconsidera o tempo em que o empregado está à disposição do empregador.

Nesse sentido, Carelli aduz que restou nítida a intenção de transformar o tempo de vida do empregado em ininterruptas horas à disposição do empregador, violando descaradamente a vida privada do trabalhador. 0 doutrinador ressalta que a relação de trabalho consiste no cerceamento temporário da liberdade do prestador de serviço, em que ele oferece seu tempo de vida em troca de remuneração ${ }^{19}$.

Ocorre que no contrato de trabalho intermitente o tempo em que o empregado se encontra à disposição do empregador é todo o tempo em que está aguardando o seu chamado, mas não recebe a devida contraprestação, de modo que a liberdade do empregado é cerceada permanentemente, sem qualquer espécie

18 MAIOR, Jorge Luiz Souto. Trabalho intermitente e golpismo constante. Revista Síntese Trabalhista, São Paulo, n. 334, p.211-215, abr. 2017. Mensal. 19 CARELLI, Rodrigo de Lacerda. Tempo à disposição é todo tempo à disposição. In: MAIOR, Jorge Luiz Souto; SEVERO, Valdete Souto (Org.). Resistência: aportes teóricos contra o retrocesso trabalhista. São Paulo : Expressão Popular, 2017. p. 273. 
de limitação, em evidente violação ao artigo $4^{\circ}$ Consolidação das Leis do Trabalho. Carelli explica:

\begin{abstract}
De considerar como tempo de trabalho todo o tempo à disposição do empregador passamos ao todo tempo de vida do trabalhador é tempo à disposição do empregador, somente considerado, por outro lado, como tempo de trabalho para fins de remuneração estritos tempos de produção, em um "Neotaylorismo" que nada mais é do que um Taylorismo ao extremo: ao invés de que em dado tempo demarcado para o trabalho busca-se organizar e cronometrar as atividades do trabalhador, coloca-se todo o tempo do trabalhador à disposição do empregador, controlando e cronometrando somente o tempo de efetiva produção do trabalhador, eliminando da folha de pagamento os tempos mortos. ${ }^{20}$
\end{abstract}

Cid pontifica que o texto reformista deve ser interpretado em correspondência à Carta Magna, de modo que a norma deveria beneficiar o prestador de serviços e não lhe retirar direitos restringindo sua jornada de trabalho apenas ao tempo de efetivo labor, como institui o parágrafo $5^{\mathrm{o}}$ do artigo $452-\mathrm{A}^{21}$ acrescido pela reforma trabalhista ${ }^{22}$.

Antagonismo acerca do tempo à disposição do empregador já fora aplicado no Brasil muito antes da sua previsão na legislação trabalhista. A empresa de fast-food, McDonald's, a partir

20 CARELLI, Rodrigo de Lacerda. Tempo à disposição é todo tempo à disposição. In: MAIOR, Jorge Luiz Souto; SEVERO, Valdete Souto (Org.). Resistência: Aportes teóricos contra o retrocesso trabalhista. São Paulo: Expressão Popular, 2017. p. 279.

$21 \S 5$ 5 0 período de inatividade não será considerado tempo à disposição do empregador, podendo o trabalhador prestar serviços a outros contratantes. BRASIL, 1943.

22 CID, Clarissa Felipe. Contrato de Trabalho intermitente e a precarização do direito do trabalho. Revista Fórum Justiça do Trabalho, Belo Horizonte, n. 398, p.57-66, fev. 2017. 
de 1995, submeteu seus empregados à chamada jornada móvel e variável, na qual seus funcionários eram contratados sem jornada determinada, sendo remunerados apenas pelo tempo de fato trabalhado, de forma que o tempo à disposição da empresa não era contabilizado. Nesse modelo de trabalho, os empregados permaneciam em uma sala dentro do local de trabalho - conhecida como sala de break - aguardando serem chamados para prestarem o serviço e o período de espera não era computado na jornada dos funcionários ${ }^{23}$.

Relativamente ao tema, o Tribunal Superior do Trabalho ${ }^{24}$ entendeu pela ilicitude da prática adotada pela empresa, sob o fundamento de que havia transferência dos riscos da atividade empresária aos empregados, que eram remunerados apenas pelo período em que prestavam os serviços, ainda que permanecessem no estabelecimento por horas, aguardando o chamado do empregador, ferindo a disposição do artigo 4o da Consolidação da Leis do Trabalho ${ }^{25}$. 0 Tribunal Regional do Trabalho também proferiu decisão ${ }^{26}$, em processo distinto, no sentido de que a ausência de fixação de carga horária ofende o princípio da comutatividade do contrato de trabalho, pois é imprescindível que as partes contratantes conheçam a extensão de suas obrigações, sendo defeso ao empregador determinar a jornada de trabalho do seu empregado de maneira arbitrária, dispondo sobre seu tempo indiscriminadamente.

23 MAEDA, Patrícia. Contrato de trabalho Intermitente. In: MAIOR, Jorge Luiz Souto; SEVERO, Valdete Souto (Org.). Resistência: Aportes teóricos contra o retrocesso trabalhista. São Paulo: Expressão Popular, 2017. Cap. 27. p. 320.

24 TST - RR - 9891900-16.2005.5.09.0004, Relator: Min Dora Maria da Costa, $8^{\text {a }}$ Turma, Data de Publicação: 25/02/2011, DEJT.

25 Art. 4o - Considera-se como de serviço efetivo o período em que o empregado esteja à disposição do empregador, aguardando ou executando ordens, salvo disposição especial expressamente consignada. BRASIL, 1943.

26 TRT-3 - RO 1700306 00388-2006-099-03-00-9, Relator: Sebastião Geraldo de Oliveira, 2 ${ }^{\text {a }}$ Turma, Data de Publicação: 25/10/2006, DJMG 
A invalidação da jornada móvel e variável se deu com fundamento nos princípios constitucionais e direitos fundamentais que proíbem o tratamento indigno do ser humano. Maeda afirma que mercantilizar o trabalho humano é infringir o princípio da dignidade da pessoa humana, pois desconsidera os direitos sociais que o trabalhador detém, reduzindo-o a mero objeto, sem considerar que se trata de uma pessoa que necessita e merece desfrutar de seu tempo como lhe for conveniente, seja com sua família, amigos ou individualmente ${ }^{27}$.

O mais sensível princípio da Constituição Federal é justamente o da dignidade da pessoa humana, que consiste na proteção do indivíduo no seu mais amplo e profundo sentido. Leciona Maurício Godinho Delgado:

O princípio da dignidade da pessoa humana traduz a idéia de que o valor central das sociedades, do Direito e do Estado contemporâneos é a pessoa humana, em sua singeleza, independentemente de seu status econômico, social ou intelectual. 0 princípio defende a centralidade da ordem juspolítica e social em torno do ser humano, subordinante dos demais princípios, regras, medidas e condutas práticas. $^{28}$

A dignidade da pessoa humana é, portanto, bússola orientadora de todo ordenamento jurídico, garantindo a valoração do ser humano como sujeito de direitos e a sua existência digna. Tal garantia constitucional pode ser vista como um supraprincípio ${ }^{29}$,

27 MAEDA, Patrícia. Contrato de trabalho Intermitente. In: MAIOR, Jorge Luiz Souto; SEVERO, Valdete Souto (Org.). Resistência: Aportes teóricos contra o retrocesso trabalhista. São Paulo: Expressão Popular, 2017. Cap. 27. p. 321.

28 DELGADO, Maurício Godinho. Direitos fundamentais na relação de trabalho. Revista de Direitos e Garantias Fundamentais, [s.l.], n. 2, p.23, 13 ago. 2007.

29 NUNES, Rizzatto. O Princípio Constitucional da Dignidade da Pessoa

Humana: doutrina e jurisprudência. São Paulo: Saraiva, 2002, p. 50. 
que se encontra acima dos demais princípios previstos na Carta Magna, irradiando para todos os ramos do direito, inclusive do trabalho. Uma das vertentes do princípio da dignidade da pessoa humana encontra-se na valorização do trabalho, pois instrumento de afirmação social, haja vista que a dignidade não atinge apenas a esfera individual do ser humano, mas também o seu plano coletivo e social ${ }^{30}$.

Dessa forma, o contrato de trabalho intermitente reduz o trabalhador à mão de obra, desconsiderando a sua qualidade de ser humano e lesando a dignidade do indivíduo e o propósito constitucional de melhoria das condições sociais do trabalhador, pois não garante ao empregado sequer o pagamento de salário mínimo mensal - sustento seu e de sua família -, tampouco o direito de conhecer seu horário de trabalho, excluindo o mínimo de garantia que até então era assegurada ao trabalhador ${ }^{31}$.

Konrath também considera a contratação de trabalho intermitente como afronta à dignidade da pessoa humana, sob o fundamento de que mercantiliza o fazer do indivíduo, tornando desprotegido o sustento, planejamento e organização financeira e familiar do trabalhador, uma vez que o empregado intermitente não possui qualquer segurança de convocação ao trabalho, precarizando, de forma escancarada, as condições de trabalho ${ }^{32}$.

Outra crítica apontada ao contrato de trabalho intermitente, por Teixeira e Gonçalves, é a exclusão do trabalhador do ambiente laboral, pois a instabilidade da relação contratual faz com que

30 DELGADO, Maurício Godinho. Direitos fundamentais na relação de trabalho. Revista de Direitos e Garantias Fundamentais, [s.l.], n. 2, p.26, 13 ago. 2007.

31 MAEDA, Patrícia. Contrato de trabalho Intermitente. In: MAIOR, Jorge Luiz Souto; SEVERO, Valdete Souto (Org.). Resistência: Aportes teóricos contra o retrocesso trabalhista. São Paulo: Expressão Popular, 2017. Cap. 27. p. 323.

32 KONRATH, Angela Maria. O contrato de trabalho intermitente. In: SEVERO, Valdete Souto et al. Comentário à Lei 13.467/17: contribuições para um enfrentamento crítico. Porto Alegre: HS Editora, 2017. p. 80. 
a passagem do empregado no estabelecimento empresarial seja breve e precária, impedindo que os trabalhadores criem ligação ou sentimento de pertencimento. Nesse contexto, o viés subjetivo de identidade do trabalhador é deixado de lado pelo explorador da atividade econômica, haja vista o alto nível de rotatividade dos empregados na empresa, ferindo a dignidade do empregado ${ }^{33}$.

A possibilidade do trabalhador se vincular a mais de um emprego, já que dependerá de várias convocações para auferir uma renda concebível, também é uma das razões pela qual o trabalho intermitente viola os direitos constitucionais do trabalhador, pois, ao se vincular a mais de um empregador, o empregado se sujeita a diversas cargas horárias e não se submete à limitação de jornada estabelecida na Carta Magna. Assim, inevitavelmente, o trabalhador será levado à exaustão, seja psíquica, porque não será convocado o número de vezes necessárias para obter uma remuneração justa - e, portanto, não terá meios financeiros de se sustentar -, seja física, pois trabalhará em diversos empregos ao mesmo tempo, sem ter uma jornada máxima respeitada.

Maeda também indica a violação à valorização do trabalho, prevista como fundamento da República Federativa do Brasil ${ }^{34}$ e da ordem econômica ${ }^{35}$, uma vez que o contrato de trabalho intermitente transfere os riscos da atividade econômica ao empregado, parte que deveria ser protegida pela legislação trabalhista, conforme será abordado no subcapítulo a seguir.

Depreende-se, assim, que a implementação do trabalho inter-

33 TEIXEIRA, Érica Fernandes; GONÇALVES, Nicolle Wagner da Silva. Afrontas ao pacto constitucional: o trabalho intermitente regulamentado e a flagrante afronta aos direitos trabalhistas no Brasil. Revista do Tribunal Regional do Trabalho da 10 ${ }^{\mathbf{a}}$ Região, Brasília, v. 21, n. 2, p.37, nov. 2016.

34 Art. 1ำ A República Federativa do Brasil, formada pela união indissolúvel dos Estados e Municípios e do Distrito Federal, constitui-se em Estado Democrático de Direito e tem como fundamentos: [...] IV - os valores sociais do trabalho e da livre iniciativa. BRASIL, 1988. (Grifos nossos).

35 Art. 170. A ordem econômica, fundada na valorização do trabalho humano e na livre iniciativa, tem por fim assegurar a todos existência digna, conforme os ditames da justiça social, observados os seguintes princípios [...]. BRASIL, 1988. (Grifos nossos). 
mitente fere diversos direitos sociais, sobretudo o da dignidade da pessoa humana, e notoriamente precariza as condições de trabalho do fornecedor da mão de obra, violando o princípio da vedação do retrocesso social, ao deixar de promover melhoria da condição social, uma vez que as normas se mostram menos favoráveis ao trabalhador, retrocedendo às frágeis normas anteriores à Consolidação das Leis do Trabalho.

\subsection{INCOMPATIBILIDADE DO CONTRATO INTERMITENTE COM AS CARACTERÍSTICAS E PRINCÍPIOS DO DIREITO DO TRABALHO}

Além de o contrato de trabalho intermitente ofender alguns dos preceitos fundamentais da Constituição Cidadã, a doutrina destaca paradoxos dessa modalidade de contratação com as características dos contratos e princípios essenciais do Direito do Trabalho.

Pinheiro aponta diversas incongruências do contrato de intermitência em relação às características básicas dos contratos de trabalho ${ }^{36}$. Refere que a contratação intermitente afronta a característica da comutatividade - quando no momento da contratação as partes já estipulam suas obrigações ${ }^{37-,}$ uma vez que o empregado será remunerado apenas pelo tempo de efetivo labor, sem, contudo, saber quando, por quanto tempo e, tampouco, se será convocado pelo empregador para prestar serviços, de modo que não há certeza da contraprestação. As obrigações do contrato de trabalho intermitente são incertas, configurando um contrato aleatório, haja vista que o empregador detém a liberdade de chamar ou não o empregado para prestar serviços, determinando, de forma arbitrária, as obrigações contratuais.

36 PINHEIRO, Iuri Pereira. Contrato de trabalho Intermitente. In: PINHEIRO, Iuri; MIZIARA, Raphael; GASPAR, Danilo (Org.). Reforma Trabalhista: e os novos Direitos Material e Processual do Trabalho. Porto Alegre: Verbo Jurídico, 2017. p. 196-197.

37 LEITE, Carlos Henrique Bezerra. Curso de Direito do Trabalho. 8. ed. São Paulo: Saraiva, 2017. p. 361. 
Quanto ao tema, Carelli pertinentemente alude que a regulação do tempo de trabalho é justamente o centro das relações trabalhistas, pois é o tempo que estipula o preço da troca realizada entre o explorador e o fornecedor da mão de obra. 0 objeto contratual das relações de trabalho é o tempo de vida do prestador de mão de obra, que fornece serviços e, consequentemente, dispõe seu tempo, de forma que o objeto contratual deve ser estipulado de maneira exata ${ }^{38}$. 0 autor salienta:

A regulação do tempo de trabalho, com a sua delimitação e limitação, é questão de impedir o enriquecimento sem causa, é dar efetividade ao caráter sinalagmático dos contratos ${ }^{39}$.

As partes conhecerem a extensões de suas obrigações é o pressuposto mais básico de qualquer contrato comutativo, afinal, é inquestionável que, nessa espécie de contrato, os contratantes devem firmar compromissos sabendo suas incumbências e responsabilidades. Assim, é transgredida a comutatividade em um contrato de trabalho intermitente, uma vez que o obreiro cumpre a sua obrigação - estar disponível ao empregador -, mas não tem certeza se perceberá uma contrapartida.

A faculdade de convocação oferecida ao detentor dos meios de produção também atinge a característica da onerosidade do contrato de trabalho, uma vez inexiste obrigatoriedade na remuneração mensal do empregado, como ressalta Silva, pois se o empregado não trabalhar em determinado mês, não perceberá

38 CARELLI, Rodrigo de Lacerda. Tempo à disposição é todo tempo à disposição. In: MAIOR, Jorge Luiz Souto; SEVERO, Valdete Souto (Org.). Resistência: Aportes teóricos contra o retrocesso trabalhista. São Paulo: Expressão Popular, 2017. p. 267.

39 CARELLI, Rodrigo de Lacerda. Tempo à disposição é todo tempo à disposição. In: MAIOR, Jorge Luiz Souto; SEVERO, Valdete Souto (Org.). Resistência: Aportes teóricos contra o retrocesso trabalhista. São Paulo: Expressão Popular, 2017.. p. 280. 
remuneração alguma, surgindo um contrato zero hora de trabalho zero remuneração. ${ }^{40}$ Todavia, no que tange à remuneração do empregado intermitente há divergências doutrinárias, ocasionadas pela omissão legislativa quanto ao tema, que será tratada no capítulo terceiro do presente artigo.

Também sustenta Pinheiro que a característica do trato sucessivo e o requisito da não-eventualidade do contrato de trabalho restam lesados na contratação intermitente, haja vista a alternância na prestação do labor, em que há dias em que o empregado trabalha e em outros permanece inativo ${ }^{41}$. Assim, em decorrência dos períodos de inatividade característicos do trabalho intermitente não se cumprem ou se renovam as prestações mês a mês, como pressupõe o contrato de trabalho.

Diante de todas as violações elencadas por Pinheiro, constata-se a irregularidade do contrato de trabalho intermitente também resultante do desrespeito à característica da alteridade, haja vista que tal modalidade de contratação transfere os riscos da atividade empresária ao empregado, parte notoriamente hipossuficiente.

A alteridade, também conhecida como assunção dos riscos do empreendimento e do trabalho, consiste, segundo Delgado, na responsabilização exclusiva do empregador sob os ônus decorrentes da atividade empresária, de modo que é o detentor dos meios de produção que assume os riscos da empresa, do estabelecimento e do contrato de trabalho ${ }^{42}$.

40 SILVA, Homero Batista Mateus da. Comentários à reforma trabalhista: Análise da lei 13.467/2017 - Artigo por artigo. São Paulo: Revista dos Tribunais Ltda., 2017, p. 46.

41 PINHEIRO, Iuri Pereira. Contrato de trabalho Intermitente. In: PINHEIRO, Iuri; MIZIARA, Raphael; GASPAR, Danilo (Org.). Reforma Trabalhista: e os novos Direitos Material e Processual do Trabalho. Porto Alegre: Verbo Jurídico, 2017. p. 196-197.

42 DELGADO, Maurício Godinho. Curso de Direito do Trabalho. 13. ed. São Paulo: LTr, 2014, Cap. XII. p. 419-420. 
A característica da alteridade é atribuída ao empregador pela legislação trabalhista, no artigo $2^{\circ}$ da Consolidação das Leis do Trabalho $^{43}$. Severo instrui que a previsão do contrato de trabalho intermitente na legislação trabalhista visa desonerar o empregador dos riscos da atividade empresária, tendo em vista que remunerará o trabalhador apenas pelo tempo de efetivo trabalho, de forma que na hipótese de crise ou de baixa demanda, quem absorverá o prejuízo será o empregado, que terá um contrato de trabalho sem remuneração, pois não será convocado ${ }^{44}$. Igualmente, Cruz ensina que a contratação intermitente desconfigura a alteridade, pois o empregador divide os riscos de empreender com o empregado, uma vez que a prestação de serviço se dá de modo fracionado, atribuindo o ônus do empreendimento também ao trabalhador diante da ausência de remuneração do tempo em que o empregado se encontra à disposição do explorador da mão de obra ${ }^{45}$.

A antinomia do contrato de trabalho intermitente e a característica da alteridade é ressaltada por Pinheiro, que pontifica que é evidente a transferência da assunção dos riscos da atividade ao empregado, pois a ausência de demanda impactará diretamente na remuneração do trabalhador, que não será convocado ao serviço, eximindo o empregador de remunerar o obreiro quando o lucro for inferior ao esperado, haja vista que não convocará o empregado ao trabalho ${ }^{46}$.

43 Art. 2o - Considera-se empregador a empresa, individual ou coletiva, que, assumindo os riscos da atividade econômica, admite, assalaria e dirige a prestação pessoal de serviço. BRASIL, 1943.

44 SEVERO, Valdete Souto. Contrato de trabalho e trabalho intermitente. In: SEVERO, Valdete Souto et al. Comentário à Lei 13.467/17: contribuições para um enfrentamento crítico. Porto Alegre: HS Editora, 2017. p. 73.

45 CRUZ, Juliana. Contrato de Trabalho Intermitente. In: GUIMARÃES, Ricardo Pereira de Freitas; MARTINEZ, Luciano. Desafios da reforma trabalhista: De acordo com a MP 808/2017 e com a Lei 13.509/2017. São Paulo: Revistas dos Tribunais, 2017. Cap. 9. p. 152.

46 PINHEIRO, Iuri Pereira. Contrato de trabalho Intermitente. In: PINHEIRO, Iuri; MIZIARA, Raphael; GASPAR, Danilo (Org.). Reforma Trabalhista: e os novos Direitos Material e Processual do Trabalho. Porto Alegre: Verbo Jurídico, 2017. p. 197. 
Teixeira e Gonçalves ainda destacam a referida violação pelo contrato de trabalho intermitente em razão da imposição do ônus da relação de trabalho ao empregado, tendo em vista que ele que terá que gerenciar seu tempo entre aguardar o chamado do empregador e procurar novos trabalhos. Afinal, o empregado terá que garantir o seu sustento com vários trabalhos concomitantes diante da alta rotatividade dos empregados intermitentes e a incerteza de convocação para o labor e, consequentemente, de remuneração ${ }^{47}$.

Evidente inversão do ônus da relação trabalhista também fere diversos princípios basilares do Direito do Trabalho. Vejamos.

Antes de analisar individualmente alguns dos princípios afetados pelo contrato de trabalho intermitente, importa referir que, segundo Lima:

Os princípios jurídicos conferem sistematicidade ao Direito e, sobretudo, ao campo em que operam, servindo de fundamentos e, ao mesmo tempo, de critérios de interpretação. Não são meros suplementos da lei ou sua mera fonte secundária, pois se encontram nos alicerces do Direito, orientando e direcionando a aplicação das normas. Os princípios se relacionam entre si, complementando-se mutuamente, e espargindo sua lucipotência às demais normas (regras), como leis, decretos, resoluções, portarias, instrumentos coletivos de trabalho, sentenças normativas etc. ${ }^{48}$

No tocante ao princípio da proteção, Plá Rodriguez o define como o amparo preferencial dado à parte mais fraca da relação,

47 TEIXEIRA, Érica Fernandes; GONÇALVES, Nicolle Wagner da Silva. Afrontas ao pacto constitucional: o trabalho intermitente regulamentado e a flagrante afronta aos direitos trabalhistas no Brasil. Revista do Tribunal Regional do Trabalho da 10 ${ }^{\mathbf{a}}$ Região, Brasília, v. 21, n. 2, p.38, nov. 2016.

48 LIMA, Francisco Gérson Marques de. Convite ao estudo da hermenêutica em direito do trabalho. São Paulo: CSB, 2017.p. 09. 
o empregado, a fim de garantir a igualdade substancial entre os contratantes $^{49}$. A hipossuficiência do trabalhador é - ou ao menos deveria ser - inquestionável, haja vista se encontrar no outro polo o explorador da atividade econômica, detentor dos meios de produção. Dessa forma, uma vez que o contrato de trabalho intermitente inevitavelmente inverte o ônus da relação e confere os riscos ao empregado, conforme fundamentos já expostos, há violação ao princípio da proteção, pois em vez de conferir um tratamento preferencial à parte mais fraca a intermitência do trabalho beneficia o empregador, que não terá que arcar com os custos do empregado quando não lhe for conveniente, deixando o trabalhador à mercê das condições do explorador da mão de obra, pois ele assumirá o risco de inexistência de remuneração.

Sugere Severo que para o contrato de trabalho intermitente se coadunar com o princípio da proteção é preciso garantir que o empregado será convocado o número de vezes necessário para que perceba como remuneração, ao menos, um salário-mínimo, evitando, assim, que o fornecedor da mão de obra se sujeite a possível situação de miserabilidade, retrocedendo à condição de mercadoria ${ }^{50}$.

Assim, faz-se necessário fortificar a aplicação do princípio da proteção para garantir o equilíbrio das relações trabalhistas tão desiguais - como a intermitente -, uma vez que o empregado se torna cada vez mais impotente frente ao poderio empresarial.

0 contrato de trabalho intermitente também fere o princípio da irrenunciabilidade dos direitos trabalhistas, que consiste na imperatividade das normas trabalhistas e impede que o trabalhador disponha de direitos legalmente assegurados ${ }^{51}$. A con-

49 RODRIGUEZ, Américo Plá. Princípios de Direito do Trabalho. 3. ed. São Paulo: LTr, 2015, p. 83.

50 SEVERO, Valdete Souto. Contrato de trabalho e trabalho intermitente. In: SEVERO, Valdete Souto et al. Comentário à Lei 13.467/17: contribuições para um enfrentamento crítico. Porto Alegre: HS Editora, 2017. p. 73-74.

51 DELGADO, Maurício Godinho. Curso de Direito do Trabalho. 13. ed. São Paulo: LTr, 2014, Cap. VI. p. 199-200. 
tratação intermitente pressupõe a renúncia de diversos direitos trabalhistas (como verificar-se-á de maneira mais aprofundada no capítulo terceiro), como, por exemplo, ao artigo $4^{\circ}$ da CLT, que determina que o tempo em que o empregado está à disposição do empregador ou está aguardando chamado é computado como tempo de efetivo serviço. Assim, uma vez que o trabalho intermitente implica a permanente espera do trabalhador pela convocação ao trabalho, já que alterna entre períodos não sabidos de atividade e inatividade, e nos períodos de espera inexiste a devida contraprestação, há evidente renúncia ao artigo $4^{\circ}$ do texto celetista, como indica Cassar ${ }^{52}$.

No que tange o princípio da continuidade da relação de emprego é evidente o desrespeito gerado pela contratação intermitente. Segundo Plá Rodriguez esse princípio representa a intenção de se atribuir às relações de emprego a duração mais longa possível, evitando, assim, a rescisão contratual ${ }^{53}$. Ocorre que o trabalho intermitente apenas por configurar relação de emprego não incentiva a continuidade da relação, mas ocasiona o efeito oposto, haja vista que o empregador detém a faculdade de convocar ou não o trabalhador, de forma que essa espécie de contratação facilita a extinção, ainda que indireta, da relação empregatícia. Afinal, ainda que o contrato de trabalho esteja em vigor, na ausência de convocação persistirá o período de inatividade, em contrariedade ao que preconiza o princípio da continuidade, provocando uma aparência de empregabilidade fictícia. Pertinentemente ao tema, Lima instrui:

Os argumentos esgrimidos para a Reforma Trabalhista, consubstanciada na Lei no $13.467 / 2017$, foi

52 CASSAR, Vólia Bomfim. Uma das novidades da reforma trabalhista: 0 contrato intermitente. LTr Suplemento Trabalhista, São Paulo, n. 084/17, 2017. Ano 53. p. 435.

53 RODRIGUEZ, Américo Plá. Princípios de Direito do Trabalho. 3. ed. São Paulo: LTr, 2015, p. 243. 


\begin{abstract}
a geração de empregos e a volta do crescimento econômico. Ora, se constitui seu fundamento a geração de empregos, obviamente a permanência dos empregos atuais se encontra no mesmo propósito e raciocínio. E se a busca é pelo crescimento econômico, os limites à rescisão contratual, que causa impacto financeiro às empresas, devem ser considerados e ampliados. Isto tudo converge para o princípio da permanência (continuidade) da relação de emprego, na esteira do que orienta a política social (não só econômica) de geração de emprego e de crescimento econômico. ${ }^{54}$
\end{abstract}

Ante o exposto, resta evidente a discrepância entre o contrato de trabalho intermitente e alguns dos princípios essenciais ao Direito do Trabalho, bem como com algumas características dos contratos trabalhistas, sendo imperiosa a interpretação do texto normativo com respaldo máximo aos princípios trabalhistas, a fim de garantir o respeito aos direitos conquistados pelos trabalhadores.

Examinada a temática principiológica do contrato de trabalho intermitente, vejamos, agora, a repercussão desta modalidade de contratação nas verbas trabalhistas.

\title{
3 REPERCUSSÃO DO CONTRATO DE TRABALHO INTERMITENTE NAS VERBAS TRABALHISTAS
}

Cumpre destacar, preliminarmente, a existência uma pequena ressalva acerca da relação empregatícia do trabalho intermitente. Cruz questiona o enquadramento do trabalho intermitente como espécie de relação de emprego, sustentando que a intermitência do serviço descaracteriza o pressuposto da não-eventualidade, devendo o trabalho ser configurado como eventual e, portanto, o fornecedor da mão de obra não deveria se enquadrar como

54 LIMA, Francisco Gérson Marques de. Convite ao estudo da hermenêutica em direito do trabalho. São Paulo: CSB, 2017. p. 19. 
empregado ${ }^{55}$. Todavia, assim como conclui a referida autora, os doutrinadores não refutam a condição de empregado do trabalhador em regime de intermitência, tendo em vista que o próprio legislador tratou esta modalidade de contratação como de emprego, sempre se utilizando das expressões empregado e empregador.

Entende-se inquestionável, pois, a condição de empregado do trabalhador submetido a contrato de trabalho intermitente. Não obstante essa condição, inúmeros direitos lhes são sonegados, ou relativizados.

De início, importa frisar que a legislação acerca do contrato de trabalho intermitente é branda, deixando lacunas quanto a diversos aspectos, uma vez que trata dessa espécie de contratação em um único artigo com nove parágrafos. Logo após a entrada em vigor do texto reformista foi editada a Medida Provisória n 808 , de 14 de novembro de 2017, que alterava novamente a Consolidação das Leis do Trabalho, incluindo diversos artigos que versavam sobre o trabalho intermitente. Todavia, em 23 de abril de 2018, a Medida Provisória teve sua vigência encerrada, pois não foi submetida ao exame do Congresso Nacional, razão pela qual a análise dos artigos que tratam sobre o trabalho intermitente será feita com base na legislação em vigor desde 11 de novembro de 2017.

A introdução desta nova modalidade de contrato de trabalho, ao alterar a espécie de prestação laboral, afetou diretamente a contraprestação percebida pelo trabalhador, ou seja, sua remuneração, em decorrência da intermitência da prestação do serviço.

0 primeiro questionamento acerca das verbas trabalhistas devidas no contrato de trabalho intermitente surge quanto a mais

55 CRUZ, Juliana. Contrato de Trabalho Intermitente. In: GUIMARÃES, Ricardo Pereira de Freitas; MARTINEZ, Luciano. Desafios da reforma trabalhista: De acordo com a MP 808/2017 e com a Lei 13.509/2017. São Paulo: Revistas dos Tribunais, 2017. Cap. 9. p. 152-153. 
básica parcela: o salário. 0 legislador estabeleceu, no caput do artigo 452-A da CLT ${ }^{56}$ que o contrato de trabalho deverá especificar o valor da hora de trabalho, que não poderá ser inferior ao valor hora do salário mínimo ou àquele devido aos empregados que exerçam a mesma função do empregado intermitente. Contudo, a legislação não refere se o empregado perceberá remuneração apenas pelas horas efetivamente trabalhadas, tampouco estipula uma convocação mínima por parte do empregador a fim de garantir o pagamento de um salário mínimo integral.

Quanto à questão, Severo defende que o caput do artigo 452A da CLT deve ser interpretado no sentido de que, ao garantir o salário hora não inferior ao mínimo, o legislador objetivou que o empregado fosse convocado ao trabalho o número de vezes necessário para auferir um salário mínimo mensal, pois interpretação diversa afrontaria a Constituição Federal, que garante em seu artigo 7ํㅜ , inciso VII, a percepção de um salário nunca inferior ao mínimo ${ }^{57}$.

Já Maeda, assim como Pinheiro, assume uma interpretação mais literal da inovação legislativa prevista na reforma trabalhista, entendendo que é possível que o empregado não perceba remuneração em alguns meses do contrato de trabalho, vez que a legislação garante apenas o valor do salário hora, sendo permitido ao empregador não convocar o empregado e, consequentemente, não remunerá-lo, se assim entender ${ }^{58}$, violando a característica

56 Art. 452-A 0 contrato de trabalho intermitente deve ser celebrado por escrito e deve conter especificamente o valor da hora de trabalho, que não pode ser inferior ao valor horário do salário mínimo ou àquele devido aos demais empregados do estabelecimento que exerçam a mesma função em contrato intermitente ou não. BRASIL, 1943.

57 SEVERO, Valdete Souto. Contrato de trabalho e trabalho intermitente. In: SEVERO, Valdete Souto et al. Comentário à Lei 13.467/17: contribuições para um enfrentamento crítico. Porto Alegre: Hs Editora, 2017. p. 73.

58 MAEDA, Patrícia. Contrato de trabalho Intermitente. In: MAIOR, Jorge Luiz Souto; SEVERO, Valdete Souto (Org.). Resistência: Aportes teóricos contra o retrocesso trabalhista. São Paulo: Expressão Popular, 2017. Cap. 27. p. 318. 
de onerosidade do contrato de trabalho, segundo Pinheiro, como tratado no subcapítulo 2.2 deste artigo.

Cruz assevera que a legislação deve ser interpretada da maneira mais benéfica ao proletariado, em conformidade ao princípio in dubio pro operario, haja vista haver mais de uma interpretação possível, prevalecendo o entendimento de que deve ser assegurado ao empregado em regime de intermitência o salário mínimo, portanto ${ }^{59}$.

Acerca da controvérsia, a $2^{\text {a }}$ Jornada de Direito Material e Processual do Trabalho elaborou enunciado sobre a remuneração do trabalho intermitente, revelando que o entendimento predominante dos magistrados da Justiça do Trabalho é no sentido de que fica garantido ao trabalhador em regime de intermitência um salário mínimo mensal, mesmo na ausência de convocação ao trabalho, a fim de compatibilizar a norma com a Constituição Federal, promovendo a proteção jurídica do salário mínimo ${ }^{60}$.

Por outro lado, assim como não determinou um período mínimo de trabalho, o legislador também não estipulou uma limitação aos chamados do empregador, alertando Nogueira para um possível desvirtuamento do contrato de trabalho intermitente, tendo em vista a faculdade do empregador em convocar o empregado quantas vezes desejar ${ }^{61}$. Nessa perspectiva, Maeda ensina que a ausência de jornada prefixada viola o artigo 7ํㅜㄹ inciso XIII, da Constituição Federal ${ }^{62}$ que prevê a limitação de jornada, inda-

59 CRUZ, Juliana. Contrato de Trabalho Intermitente. In: GUIMARÃES, Ricardo Pereira de Freitas; MARTINEZ, Luciano. Desafios da reforma trabalhista: De acordo com a MP 808/2017 e com a Lei 13.509/2017. São Paulo: Revistas dos Tribunais, 2017. Cap. 9. p. 154-155.

60 JORNADA DE DIREITO MATERIAL E PROCESSUAL DO TRABALHO, 2., 2017, Brasília. Enunciados aprovados na 2aㅡ Jornada. Brasília: Anamatra, 2017. 1 v.

61 NOGUEIRA, Eliana dos Santos Alves. O contrato de trabalho intermitente na reforma trabalhista: contraponto com o modelo italiano. In: ESCOLA JUDICIAL DO TRT 15 (Campinas). Revista do Tribunal Regional do Trabalho da 15a Região. 51. ed. Campinas: Escola Judicial do TRT 15, 2017. p. 136. ${ }^{62}$ Art. 7ํㅗ̃o direitos dos trabalhadores urbanos e rurais, além de outros que 
gando como será definido o trabalho extraordinário se sequer se conhece o trabalho ordinário.

A respeito das demais parcelas trabalhistas, o parágrafo $6^{0}$ do artigo 452-A da CLT dispõe:

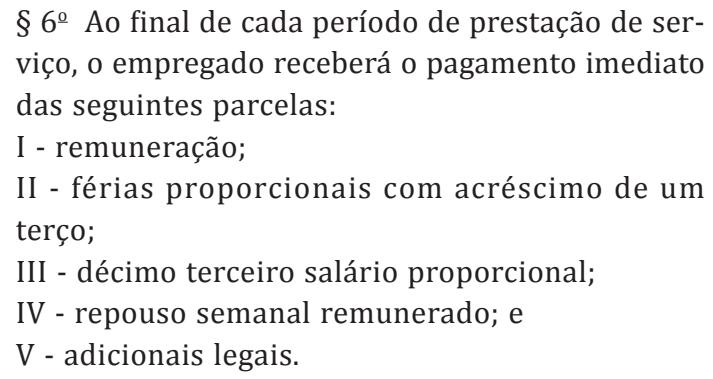

Referente ao trecho legal observa-se que o legislador não especificou qual é o referido período de prestação de serviço, permitindo interpretações diversas, propondo Nogueira que a periodicidade máxima seja de trinta dias, com o pagamento até o quinto dia útil do mês subsequente, em conformidade com o artigo 459 do texto celetista ${ }^{63}$.

No tocante o pagamento das férias proporcionais, Nogueira aponta a inconstitucionalidade da norma por suprimir a contemporaneidade entre o pagamento acrescido do terço constitucional e a fruição do descanso ${ }^{64}$. Severo ressalta que o parcelamento das

visem à melhoria de sua condição social: [...] XIII - duração do trabalho normal não superior a oito horas diárias e quarenta e quatro semanais, facultada a compensação de horários e a redução da jornada, mediante acordo ou convenção coletiva de trabalho. BRASIL, 1988.

63 NOGUEIRA, Eliana dos Santos Alves. O contrato de trabalho intermitente na reforma trabalhista: contraponto com o modelo italiano. In: ESCOLA JUDICIAL DO TRT 15 (Campinas). Revista do Tribunal Regional do Trabalho da 15a Região. 51. ed. Campinas: Escola Judicial do TRT 15, 2017. p. 137. NOGUEIRA, Eliana dos Santos Alves. 0 contrato de trabalho intermitente na reforma trabalhista: contraponto com o modelo italiano. In: ESCOLA JUDICIAL DO TRT 15 (Campinas). Revista do Tribunal Regional do Trabalho da 15⿳a Região. 51. ed. Campinas: Escola Judicial do TRT15, 2017. p. 138. 
férias transforma esse direito à desconexão, assim como ocorre no repouso semanal remunerado, em mera remuneração, uma vez que a parcela não será utilizada ao que se propõe ${ }^{65}$.

Ademais, o parágrafo 9o do artigo 452-A da CLT ${ }^{66}$ refere que o empregado adquire a cada doze meses o direito a um mês de férias, no qual não poderá ser convocado para trabalhar pelo mesmo empregador, esvaziando o sentido de ser das férias diante da possibilidade de o empregado prestar serviços a outro empregador, desviando a finalidade dessa garantia constitucional, que é assegurar o repouso do trabalhador, a fim de proteger a sua saúde física e mental. Maeda alude que a redação do parágrafo resguarda apenas o direito de o obreiro não ser convocado, sem proteger o direito ao descanso remunerado, de modo que o empregado ficaria um mês sem trabalhar, mas sem receber, no verdadeiro contrato zero trabalho zero remuneração ${ }^{67}$.

0 mesmo rompimento de finalidade é constatado no décimo terceiro, uma vez que o pagamento da parcela objetiva fomentar a economia com as vendas de fim de ano, possibilitando que os trabalhadores financiem seus gastos nesse período de elevado consumo, de forma que o pagamento proporcional prejudica o sentido da verba trabalhista ${ }^{68}$.

No que tange o Fundo de Garantia por Tempo de Serviço e a contribuição previdenciária, o parágrafo $8^{0}$ do artigo em aná-

65 SEVERO, Valdete Souto. Contrato de trabalho e trabalho intermitente. In: SEVERO, Valdete Souto et al. Comentário à Lei 13.467/17: contribuições para um enfrentamento crítico. Porto Alegre: HS Editora, 2017. p. 75.

66 § 9 A cada doze meses, o empregado adquire direito a usufruir, nos doze meses subsequentes, um mês de férias, período no qual não poderá ser convocado para prestar serviços pelo mesmo empregador. BRASIL, 1943. MAEDA, Patrícia. Contrato de trabalho Intermitente. In: MAIOR, Jorge Luiz Souto; SEVERO, Valdete Souto (Org.). Resistência: Aportes teóricos contra o retrocesso trabalhista. São Paulo: Expressão Popular, 2017. Cap. 27. p. 319.

68 SEVERO, Valdete Souto. Contrato de trabalho e trabalho intermitente. In: SEVERO, Valdete Souto et al. Comentário à Lei 13.467/17: contribuições para um enfrentamento crítico. Porto Alegre: HS Editora, 2017. p. 75. 
lise $^{69}$ dispõe que o empregador deverá efetuar o recolhimento da contribuição e o depósito do FGTS com base nos valores pagos no mês, de modo que, nos meses em que o empregado não for convocado, não perceberá FGTS nem terá contribuição previdenciária recolhida, contrariando as garantias asseguradas pela relação de emprego. Assim, a conclusão lógica é no sentido de imenso prejuízo à aposentadoria do empregado intermitente, tendo em vista que seus recolhimentos previdenciários ocorrerão de forma esporádica, retardando o processo de aposentadoria significativamente. 0 mesmo se verifica no FGTS, uma vez que os valores depositados serão pequenos e, em possível situação de desemprego, o trabalhador não terá uma reserva de dinheiro suficiente a garantir a sua subsistência.

Os parágrafos $1^{\mathrm{o}}$ a $4^{\mathrm{o}}$ do artigo $452-\mathrm{A}$ da $\mathrm{CLT}^{70}$ versam sobre a convocação do empregado intermitente ao trabalho:

$\S 1^{0} 0$ empregador convocará, por qualquer meio de comunicação eficaz, para a prestação de serviços, informando qual será a jornada, com, pelo menos, três dias corridos de antecedência.

$\S 2^{\circ}$ Recebida a convocação, o empregado terá o prazo de um dia útil para responder ao chamado, presumindo-se, no silêncio, a recusa. $\S 3^{\circ}$ A recusa da oferta não descaracteriza a subordinação para fins do contrato de trabalho intermitente.

$\S 4^{\circ}$ Aceita a oferta para o comparecimento ao trabalho, a parte que descumprir, sem justo motivo, pagará à outra parte, no prazo de trinta dias, multa de 50\% (cinquenta por cento) da remuneração que seria devida, permitida a compensação em igual prazo.

$69 \S 8^{0} 0$ empregador efetuará o recolhimento da contribuição previdenciária e o depósito do Fundo de Garantia do Tempo de Serviço, na forma da lei, com base nos valores pagos no período mensal e fornecerá ao empregado comprovante do cumprimento dessas obrigações. BRASIL, 1943.

70 BRASIL. Decreto-lei no 5.452, de 01 de maio de 1943. Diário Oficial da União, Rio de Janeiro, 01 maio 1943. 
A previsão normativa que estipula o pagamento de multa foi refutada pela doutrina, que indica pela inconstitucionalidade do texto legal. Colnago expõe que a imposição de multa do empregado desrespeita a alteridade do contrato de trabalho, haja vista o risco da atividade ser do empregador. A autora refere que o detentor do capital produtivo é o empregador, não tendo o empregado condições de arcar com o pagamento da multa, principalmente ante o caráter impenhorável do salário ${ }^{71}$.

Nesse diapasão, Severo instrui que a multa somente pode ser aplicada em relação ao empregador, diante do caráter intangível do salário, que é protegido pelo artigo 7o, inciso X, da Constituição Cidadã. A magistrada cita a Convenção 95 da OIT que veda qualquer desconto ao salário para garantir o pagamento do trabalhador ao empregador, com o objetivo de preservar ou obter o emprego ${ }^{72}$. Nogueira, por sua vez, pontifica que o legislador sequer estipulou o que seria justo motivo para o empregado faltar ao trabalho, dando subjetividade à interpretação da norma ${ }^{73}$.

Por fim, no que concerne às verbas rescisórias, a legislação nada dispôs, resultando em diversos questionamentos que, após um ano de vigência da lei, ainda não foram elucidados.

A Medida Provisória no 808 tratou da extinção do contrato em regime de intermitência, referindo que decorrido o prazo de um ano sem convocação pelo empregador o contrato estaria encerrado de pleno direito, sendo devido, pela metade, o aviso prévio indenizado (que seria calculado com base nos valores percebidos

71 COLNAGO, Lorena de Mello Rezende. Trabalho intermitente - trabalho "zero hora" - trabalho fixo descontínuo: a nova legislação e a reforma da reforma. Revista LTr, São Paulo, v. 82, n. 01, p.41-42, jan. 2018. Mensal.

72 SEVERO, Valdete Souto. Contrato de trabalho e trabalho intermitente. In: SEVERO, Valdete Souto et al. Comentário à Lei 13.467/17: contribuições para um enfrentamento crítico. Porto Alegre: HS Editora, 2017. p. 74.

73 NOGUEIRA, Eliana dos Santos Alves. 0 contrato de trabalho intermitente na reforma trabalhista: contraponto com o modelo italiano. In: ESCOLA JUDICIAL DO TRT 15 (Campinas). Revista do Tribunal Regional do Trabalho da 15a Região. 51. ed. Campinas: Escola Judicial do TRT 15, 2017. p. 136. 
na vigência do contrato) e a indenização sobre o saldo do FGTS, sendo devidas as demais parcelas trabalhistas na integralidade. A percepção pela metade do aviso prévio e da indenização do FGTS contrariam completamente o aplicável às relações de emprego, uma vez que o poder de convocação ao trabalho é do empregador, de modo que ao não chamar o trabalhador para prestar serviço está, pouco a pouco, rescindindo o contrato de trabalho, não havendo qualquer razão para que as referidas verbas fossem pagas pela metade, como ocorre na culpa recíproca. Reputamos, inclusive, que deveria haver uma penalidade ao empregador, tendo em vista que mesmo não desejando manter a relação de emprego, não dispensa o empregado, mantendo-o à sua disposição por um ano, sem que ele perceba qualquer remuneração.

Todavia, como já referido, a Medida Provisória perdeu sua validade, restando uma legislação precária, repleta de lacunas, que impedem maiores entendimentos e debates sobre a espécie de contratação, impossibilitando, em certa medida, a aplicação do trabalho intermitente.

Analisada a repercussão do contrato de trabalho intermitente nas verbas trabalhistas, avançamos à averiguação dos possíveis impactos dessa modalidade de contratação no mercado de trabalho brasileiro, sob a perspectiva econômica.

\section{POSSÍVEIS IMPACTOS DA ADOÇÃO DO CONTRATO DE TRABALHO INTERMITENTE SOB A PERSPECTIVA ECONÔMICA}

De modo geral, a reforma trabalhista foi pautada na justificativa de ser imperiosa a renovação da Consolidação das Leis do Trabalho, pois tratava-se de uma legislação ultrapassada e excessivamente protecionista, que ocasionava a sobrecarga da Justiça do Trabalho e, consequentemente, altos custos aos detentores do meio de produção ${ }^{74}$.

74 TEIXEIRA, Érica Fernandes; GONÇALVES, Nicolle Wagner da Silva. Afrontas ao pacto constitucional: o trabalho intermitente regulamentado e a flagrante afronta aos direitos trabalhistas no Brasil. Revista do Tribunal Regional do Trabalho da 10 ${ }^{\mathbf{a}}$ Região, Brasília, v. 21, n. 2, p.32, nov. 2016. 
No que concerne especificamente ao fundamento apresentado para introdução do contrato de trabalho intermitente na legislação trabalhista, Pinheiro aponta como uma das justificativas utilizadas - defendida por Amauri Mascaro Nascimento e Almir Pazzianotto -, o dever de regulamentação de bicos, pois trata-se de inegável prática social, sendo imprescindível que o direito se adapte às situações cotidianas, a fim de garantir segurança aos contratantes ${ }^{75}$. Também se defendeu a inserção desta modalidade de contratação sob o argumento de que, por regularizar os serviços informais, o trabalho em regime intermitente acarretaria o aumento dos postos de trabalho e reduziria os altos índices de desemprego que assolam o Brasil, desenvolvendo a economia do país ${ }^{76}$.

Frente a essas justificativas, faz-se necessário o retorno às noções introdutórias do Direito do Trabalho - ligeiramente elencadas no início deste artigo - a fim de ressalvar que o condão das normas trabalhistas é nivelar as relações de trabalho firmadas entre o detentor do capital produtivo e o trabalhador que tem sua mão de obra explorada. A disparidade entre os contratantes exige um sistema de proteção que contrabalance o poderio empresarial e a vulnerabilidade dos operários.

O Direito do Trabalho não se presta, portanto, a fomentar o desenvolvimento econômico do país ou aumentar os postos de trabalho, sobretudo se para tanto tivesse de romper com seus preceitos, beneficiando o detentor dos meios de produção e permitindo a exploração laboral desigual, como propôs o texto reformista. Seria no mínimo ilógico que o instituto que tem função assecuratória dos direitos conquistados pela classe trabalhadora

75 PINHEIRO, Iuri Pereira. Contrato de trabalho Intermitente. In: PINHEIRO, Iuri; MIZIARA, Raphael; GASPAR, Danilo (Org.). Reforma Trabalhista: e os novos Direitos Material e Processual do Trabalho. Porto Alegre: Verbo Jurídico, 2017. p. 187-188.

76 FERNANDES, Paulo Roberto. A figura do contrato de trabalho intermitente do PL no 6.787/2016 (Reforma Trabalhista) à luz do direito comparado. 2017. 
tivesse também o escopo de socorrer o país da crise econômica. O Direito do Trabalho é um ramo autônomo que, embora impacte na economia do país por regular as relações laborais, não carrega função econômica, nem mesmo deveria, pois perderia sua razão de existir, como destaca Nelson ${ }^{77}$.

Feita a ressalva quanto à separação do Direito do Trabalho da economia, importa analisar os possíveis efeitos da adoção do contrato de trabalho intermitente no Brasil sob a perspectiva econômica, haja vista se tratar de um dos argumentos utilizados para regulamentação dessa nova espécie de contratação, a fim de averiguar se o contrato de trabalho intermitente efetivamente poderá servir ao que se propõe.

Para tanto, é preciso examinar os efeitos observados nos países em que contratos de trabalho similares ao intermitente foram implantados, tais como Itália e Reino Unido.

Contrato semelhante ao intermitente, em que há alternância de períodos de trabalho e de inatividade, foi instituído no Reino Unido, em 1996, pela modalidade zero-hour contrat. Segundo Charão e Villatore, assim como estabelecido no texto celetista, a legislação inglesa não garante um mínimo de horas que devam ser trabalhadas, tampouco assegura a percepção de um salário mínimo, razão pela qual se verifica a vinculação dos empregados ingleses a mais de um empregador, a fim de garantirem a sua subsistência ${ }^{78}$

A Itália, por sua vez, introduziu o contrato de trabalho intermitente - também conhecido como contrato a chamada - em

77 NELSON, Rocco Antônio Rangel Rosso. Da flexibilização das relações de trabalho e a consequente violação do mínimo existencial do trabalhador. Revista Espaço Acadêmico, Maringá, v. 17, n. 200, p. 27, jan. 2018.

78 CHARÃO, Anderson Pereira; VILLATORE, Marco Antônio César. O contrato de trabalho intermitente na reforma laboral e os danos ao trabalhador. In: STÜRMER, Gilberto; DORNELES, Leandro do Amaral D. de (Org.). A reforma trabalhista: Na visão acadêmica. Porto Alegre: Verbo Jurídico, 2018. p. 121-123. 
2003, o qual sofreu renovação em 2015, por meio de um Decreto legislativo. A legislação italiana, todavia, aplica uma espécie de indenização de disponibilidade ao empregado, que será paga mês a mês, em razão do tempo em que o trabalhador se coloca à disposição do empregador ${ }^{79}$.

Nos referidos países, em que regulamentaram a contratação de empregados de forma análoga à intermitente, observou-se um aumento na quantidade de postos de trabalhos em regime de tempo parcial, conforme indica os dados de Tranding Economics $^{80}$. Contudo, a experiência do Reino Unido, segundo Charão e Villatore, indica que o contrato de trabalho intermitente impacta diretamente no aumento de pessoas em situação de subemprego ${ }^{81}$, havendo, em verdade, um mascaramento dos índices de desemprego. Na Itália, a repercussão acarretada pelo contrato em regime de intermitência foi semelhante: as estatísticas apontam que esta modalidade de contrato implicou, a curto prazo, o aumento do número de trabalhadores pobres e, em longo prazo, implicará o aumento de aposentados pobres ${ }^{82}$.

De acordo com Reis e Costa, o uso de jornada de trabalho similar à intermitente está associado a remunerações mais baixas

79 NOGUEIRA, Eliana dos Santos Alves. O contrato de trabalho intermitente na reforma trabalhista: contraponto com o modelo italiano. In: ESCOLA JUDICIAL DO TRT 15 (Campinas). Revista do Tribunal Regional do Trabalho da 15 a Região. 51. ed. Campinas: Escola Judicial do TRT 15, 2017. p. 140-145.

80 TRADING ECONOMICS. Disponível em: <https://tradingeconomics.com/>. Acesso em: 13 de nov. 2018

81 CHARÃO, Anderson Pereira; VILLATORE, Marco Antônio César. O contrato de trabalho intermitente na reforma laboral e os danos ao trabalhador. In: STÜRMER, Gilberto; DORNELES, Leandro do Amaral D. de (Org.). A reforma trabalhista: Na visão acadêmica. Porto Alegre: Verbo Jurídico, 2018. p. 121-122.

82 NOGUEIRA, Eliana dos Santos Alves. O contrato de trabalho intermitente na reforma trabalhista: contraponto com o modelo italiano. In: ESCOLA JUDICIAL DO TRT 15 (Campinas). Revista do Tribunal Regional do Trabalho da 15a Região. 51. ed. Campinas: Escola Judicial do TRT 15, 2017. p. 144. 
do que as oferecidas nos postos de trabalho de tempo integral ${ }^{83}$. Constata-se que, em que pese o trabalho intermitente possibilite o crescimento do número de cidadãos empregados, suas remunerações são precárias, impossibilitando que a empregabilidade produza os efeitos positivos que se pretende.

Compreende-se, assim, que a adoção de contratos intermitentes produziria efeitos nefastos na distribuição de renda, aumentando cada vez mais as desigualdades sociais, já tão acentuadas no Brasil. Isso porque, conforme os economistas Almeida e Guilhoto, a economia forma um fluxo circular, haja vista que os salários recebidos pelos trabalhadores estimulam o consumo de bens e serviços, que, por sua vez, são ofertados pelo setor produtivo (responsável pelo pagamento dos salários):

A estrutura de distribuição de renda determina, em grande parte, o padrão de consumo das famílias; por sua vez os bens e serviços consumidos são ofertados pelo setor produtivo da economia, que para produzi-los paga salários em suas diversas atividades, fechando assim o fluxo circular da renda. ${ }^{84}$

0 aumento da concentração da renda provocado pela nova modalidade de contratação, não apenas concorre para a dilapidação dos ganhos sociais ocorridos durante a primeira década do século XXI - valorização do salário mínimo, redução da desigualdade social, inserção de classes marginalizadas na educação superior, entre outros - como também pode comprometer o crescimento econômico que, conforme os autores da proposta legislativa, seria proporcionado com o aumento da flexibilização das normas trabalhistas.

83 REIS, Maurício; COSTA, Joana. Jornada de Trabalho parcial no Brasil. Brasília: IPEA: MTPS, 2016.

84 ALMEIDA, Leandro de Oliveira; GUILHOTO, Joaquim José Martins. Crescimento econômico e distribuição de renda: uma análise a partir das estruturas econômicas do Brasil contemporâneo. Salvador: ANPEC, 2006. 
Nesse aspecto, Teixeira e Gonçalves defendem a contratação de trabalho fixo e contínuo, sob o argumento de que o trabalhador que tem segurança na relação de emprego - tendo sua remuneração mensal garantida pela modalidade de contrato - e está dignamente inserido no mercado de trabalho, possui maior produtividade e segurança para realizar o consumo de bens de maior valor agregado, promovendo, desta forma, uma corrente de melhorias para a sociedade, fomentando a economia do país, além de gerar o aumento de direitos e permitir uma melhor distribuição de renda ${ }^{85}$. Nesse diapasão, as doutrinadoras referem:

A garantia dos direitos da classe trabalhadora é a chave para o desenvolvimento econômico e social - e não a criação de inúmeros postos de trabalho precários e escravizantes. ${ }^{86}$

Ocorre que nos contratos de trabalho o objeto contratual é a prestação de serviço, estipulada por meio do valor hora, que definirá a remuneração do obreiro, a depender do número total de horas trabalhadas pelo empregado. É inquestionável, diante de todo o exposto até este ponto, que o contrato de trabalho intermitente visa a redução da carga horária do trabalhador, justamente por pressupor a alternância entre os períodos de atividade e inatividade - independentemente da interpretação a ser adotada acerca da remuneração do empregado intermitente. Sendo assim, é fácil concluir que a contratação intermitente, em decorrência da redução das horas trabalhadas pelo empregado,

85 TEIXEIRA, Érica Fernandes; GONÇALVES, Nicolle Wagner da Silva. Afrontas ao pacto constitucional: o trabalho intermitente regulamentado e a flagrante afronta aos direitos trabalhistas no Brasil. Revista do Tribunal Regional do Trabalho da 10 ${ }^{\mathbf{a}}$ Região, Brasília, v. 21, n. 2, p.37, nov. 2016.

86 TEIXEIRA, Érica Fernandes; GONÇALVES, Nicolle Wagner da Silva. Afrontas ao pacto constitucional: o trabalho intermitente regulamentado e a flagrante afronta aos direitos trabalhistas no Brasil. Revista do Tribunal Regional do Trabalho da 10ª Região, Brasília, v. 21, n. 2, p.40, nov. 2016. 
implicará na redução da sua remuneração mensal, salvo raras exceções, uma vez que o objeto do contrato é o valor hora.

Dessa forma, não se mostra racional incentivar a adoção do contrato de trabalho intermitente sob o argumento de que fomentará a economia nacional, se essa espécie de contratação acarretará a redução da média salarial e, consequentemente, reduzirá o consumo por parte do proletariado, um dos principais meios de fomento econômico.

Depreende-se, portanto, que a intenção do legislador reformista não é solucionar a crise econômica brasileira, haja vista que a criação de postos de trabalho precários, por si só, não fomentaria a economia, apenas manteria ou diminuiria o poder de compra das grandes massas. Da mesma forma, a redução salarial não só gera a redução do consumo por parte do proletariado, como também aumenta os níveis de desigualdade social, tendo em vista o crescimento da concentração de renda na mão de poucos. Assim, ineficaz a adoção do contrato de trabalho intermitente para reduzir os índices de desemprego.

No tocante à justificativa de implementação do contrato de trabalho intermitente para regularização de trabalhos informais, a legislação também se mostra incoerente. A doutrina apresenta duras críticas ao contrato de trabalho intermitente justamente no que se refere à restrição da adoção desta modalidade contratual apenas aos aeronautas, uma vez que um dos principais argumentos para instauração dessa espécie de contrato era a necessidade de regulamentação de bicos, por resguardar os direitos de trabalhadores eventuais, tais como músicos e garçons ${ }^{87}$.

Todavia, a Lei no $13.467 / 2017$ vedou a contratação de trabalho intermitente apenas de aeronautas, não restringindo o

87 PINHEIRO, Iuri Pereira. Contrato de trabalho Intermitente. In: PINHEIRO, Iuri; MIZIARA, Raphael; GASPAR, Danilo (Org.). Reforma Trabalhista: e os novos Direitos Material e Processual do Trabalho. Porto Alegre: Verbo Jurídico, 2017. p. 188. 
efeito da norma apenas aos trabalhadores esporádicos, como se esperava. Charão e Villatore acreditam que tal forma de introdução do trabalho intermitente, por não o delimitar às atividades que se destina, acaba por incentivar a precarização das relações de trabalho, uma vez que a modalidade de emprego pode ser ampliada a qualquer atividade econômica, excetuados somente os aeronautas. Os doutrinadores afirmam que para a norma prevista na reforma trabalhista sirva ao que se propõe, o contrato de trabalho intermitente só deverá ser adotado quando a atividade explorada pelo empregador tiver caráter de intermitência, a justificar a aplicação dessa espécie de contrato de trabalho, uma vez que sua utilização irrestrita acabaria por precarizar as relações de trabalho ${ }^{88}$.

Pinheiro ainda ressalta que não há nenhum impedimento ao empregador de substituir de imediato os contratos de emprego de caráter fixo e contínuo por contratos de trabalho intermitente, mas defende que a legislação em questão - em analogia ao Direito Português - deveria ser aplicada apenas nos casos em que os trabalhadores não se enquadrem no conceito tradicional de empregado, a fim de evitar que o contrato de trabalho intermitente seja aplicado indiscriminadamente e aumente os índices de subemprego ${ }^{89}$.

O que se conclui, portanto, é que, em que pese o argumento utilizado pelo legislador para instauração do contrato de trabalho intermitente tenha sido a regulamentação de bicos e a concessão de maior flexibilidade às atividades econômicas que possuem

88 CHARÃO, Anderson Pereira; VILLATORE, Marco Antônio César. O contrato de trabalho intermitente na reforma laboral e os danos ao trabalhador. In: STÜRMER, Gilberto; DORNELES, Leandro do Amaral D. de (Org.). A reforma trabalhista: Na visão acadêmica. Porto Alegre: Verbo Jurídico, 2018. p. 119-129.

89 PINHEIRO, Iuri Pereira. Contrato de trabalho Intermitente. In: PINHEIRO, Iuri; MIZIARA, Raphael; GASPAR, Danilo (Org.). Reforma Trabalhista: e os novos Direitos Material e Processual do Trabalho. Porto Alegre: Verbo Jurídico, 2017. p. 195. 
demanda altamente variáveis - como hotéis, restaurantes e setor de eventos -, a legislação reformista não contemplou tal justificativa, permitindo a aplicação do modelo a todas as atividades econômicas, ressalvando apenas os aeronautas ${ }^{90}$.

É evidente, portanto, a pretensão do legislador de apenas mascarar os índices de desemprego ao introduzir o contrato de trabalho intermitente na legislação trabalhista. Maeda ressalta que a intenção de ocultar a crítica situação de desemprego - enquanto afasta os direitos dos trabalhadores e reduz a massa salarial - aumenta a vulnerabilidade do empregado frente ao empregador, o deixando ainda mais submisso às condições do explorador da mão de obra ${ }^{91}$. Nesse sentido, Zygmunt Bauman leciona:

Ameaçar com o desemprego ou recusar o emprego permite conquistar ou manter o domínio com um gasto de energia, tempo e dinheiro muito inferior ao exigido para controlar e vigiar de maneira invasiva. A ameaça do desemprego desloca o ônus da prova para a parte adversa, ou seja, para os dominados. Cabe agora aos subordinados adotar um comportamento que tenha boas chances de agradar aos chefes e de estimulá-los a "adquirir" seus serviços e seus "produtos" particulares - exatamente como os outros produtores e revendedores estimulam em seus potenciais consumidores o desejo de comprar as mercadorias que vendem. "Seguir rotinas" não basta para atingir esse objetivo."92

90 MAEDA, Patrícia. Contrato de trabalho Intermitente. In: MAIOR, Jorge Luiz Souto; SEVERO, Valdete Souto (Org.). Resistência: Aportes teóricos contra o retrocesso trabalhista. São Paulo: Expressão Popular, 2017. Cap. 27. p. 322.

91 MAEDA, Patrícia. Contrato de trabalho Intermitente. In: MAIOR, Jorge Luiz Souto; SEVERO, Valdete Souto (Org.). Resistência: Aportes teóricos contra o retrocesso trabalhista. São Paulo: Expressão Popular, 2017. Cap. 27. p. 325.

92 BAUMAN, Zygmunt. Capitalismo parasitário: e outros temas contemporâneos. Rio de Janeiro: Zahar, 2010. p. 52. 
Averigua-se, por conseguinte, que as justificativas apresentadas pelos defensores da inserção do contrato de trabalho intermitente são falaciosas, haja vista que o legislador não assegurou meios para que realmente houvesse a regulamentação dos trabalhos informais, tampouco gerasse melhoria na economia do país, demonstrando que o que se pretendeu, em verdade, foi a retirada de direitos para reduzir os custos dos serviços prestados aos exploradores da mão de obra.

\section{CONSIDERAÇÕES FINAIS}

Este artigo objetivou examinar o tratamento justrabalhista dado ao contrato de trabalho intermitente pelas inovações legislativas introduzidas com a vigência da Reforma Trabalhista (Lei $\mathrm{n}^{\circ}$ 13.467 de 2017). Para tanto, analisou-se a nova forma de contratação sob a luz dos princípios constitucionais e dos preceitos fundamentais do Direito do Trabalho brasileiro. Abordou-se também os possíveis impactos econômicos que o contrato de trabalho intermitente poderia causar na sociedade brasileira, buscando compreender como a adoção dessa inovação trabalhista impacta os direitos garantidos aos trabalhadores.

O Direito do Trabalho, instituto responsável por regular as relações entre o detentor do capital produtivo e o trabalhador que fornece sua mão de obra, possui como principal premissa a proteção do polo mais frágil da relação. A atuação da Justiça do Trabalho, em conjunto com a legislação trabalhista, desempenha um importantíssimo papel na sociedade capitalista ao atenuar a disparidade entre o poderio empresarial e o proletariado, com o escopo de impedir que os trabalhadores sejam subjugados à condição de mero objeto sem que lhes seja respeitada a sua dignidade humana.

As árduas lutas das classes trabalhadoras conquistaram, pouco a pouco, que o proletariado tenha direitos frente ao seu empregador, garantindo que a sua dignidade seja assegurada e 
que seu papel no sistema de produção seja valorizado. Hoje, anos após as conquistas dos trabalhadores, vivemos uma onda mundial de flexibilização que acarreta a retirada dos direitos trabalhistas, no intuito de baratear a exploração da mão de obra pela minoria detentora do capital produtivo.

O Estado tem o condão de garantir os direitos dos cidadãos e evitar que a dignidade da pessoa humana seja ameaçada, sempre assegurando o seu crescimento social, com base no princípio da vedação do retrocesso social. Contudo, não foi o que se verificou na reforma trabalhista. A inserção do contrato de trabalho intermitente na legislação trabalhista é reflexo perfeito do cenário que os trabalhadores vêm enfrentando, em que, cada vez mais, têm seus direitos cassados em nome de um suposto desenvolvimento econômico.

Analisado o texto reformista, sob a luz da Constituição da República Federativa do Brasil e dos preceitos do Direito do Trabalho, evidenciou-se um imenso retrocesso social, em desrespeito a diversas garantias fundamentais, de observância obrigatória. Sujeitar o empregado a um vínculo de emprego que não garante a percepção de um salário mensal, tampouco o pagamento das verbas trabalhistas, em um regime de disponibilidade permanente, é mercantilizar o trabalhador, retrocedendo aos ideais do século XVIII. A transferência dos riscos da atividade econômica ao empregado e o sepultamento do direito à desconexão eliminam a condição humana dos trabalhadores em regime de intermitência.

Evidenciou-se, por fim, que os fundamentos elencados pelos defensores do contrato de trabalho intermitente se tratam apenas de promessas falaciosas com o escopo de justificar a introdução de um contrato de trabalho precarizante. A aplicação do contrato de trabalho com a lógica inversa do Direito do Trabalho traça um cenário inquestionável de sonegação de direitos básicos dos trabalhadores, que relativiza completamente verbas trabalhistas que deveriam garantir a subsistência do empregado. 
Cumpre salientar, inclusive, que o texto reformista dificulta a análise da nova modalidade de contratação e a interpretação pelos hermeneutas, tendo em vista que o legislador aprovou a reforma as pressas, sem se preocupar em esclarecer questões primordiais para aplicação de qualquer contrato de trabalho, esvaziando o fundamento de diversos direitos trabalhistas.

Assim, diante de tamanhas lacunas e contradições, é imprescindível que o Direito atue fortemente contra a flexibilização das garantias constitucionais e faça valer seus preceitos, impondo respeito aos princípios trabalhistas que detêm força vinculante tanto quanto às normas positivadas. Afinal, a brecha na legislação possibilita interpretações nos mais variados sentidos, devendo sempre prevalecer a interpretação mais favorável ao trabalhador, em razão do princípio in dubio pro operario.

Nesse aspecto, ainda que a legislação assim permita, compreende-se que o contrato de trabalho intermitente só poderá ser adotado nas hipóteses de serviços em caráter de intermitência. Caso contrário, estaremos diante de um desvirtuamento do instituto e de uma completa inversão da lógica justrabalhista, correndo risco de ter todos os trabalhos em tempo integral convertidos em contratos intermitentes.

Por todo exposto neste artigo, conclui-se que a incompatibilidade do contrato de trabalho intermitente com o ordenamento jurídico brasileiro é evidente, apontando a inconstitucionalidade dessa modalidade de contratação, razão pela qual estaria impedida a adoção do regime de trabalho intermitente da forma prevista na legislação. Todavia, diante da probabilidade de aplicação deste contrato de trabalho, mostra-se imperioso que o instituto seja interpretado e aplicado com base nos princípios trabalhistas e constitucionais, em especial os da dignidade da pessoa humana e da proteção ao trabalho, a fim de amenizar a precarização da relação laboral. 


\section{REFERÊNCIAS}

ALMEIDA, Almiro Eduardo de; SEVERO, Valdete Souto. Direito do Trabalho: Avesso da precarização. São Paulo: LTr, 2014.

ALMEIDA, Leandro de Oliveira; GUILHOTO, Joaquim José Martins. Crescimento econômico e distribuição de renda: uma análise a partir das estruturas econômicas do Brasil contemporâneo. Salvador: ANPEC, 2006. Disponível em: <http://www.anpec.org.br/encontro2006/artigos/ A06A049.pdf>. Acesso em: 13 nov. 2018.

BAUMAN, Zygmunt. Capitalismo parasitário: e outros temas contemporâneos. Rio de Janeiro: Zahar, 2010.

BRASIL. Constituição da república federativa do brasil de 1988. Diário Oficial da União, Brasília, 1988. Disponível em: <http://www.planalto. gov.br/ccivil_03/constituicao/constituicaocompilado.htm>. Acesso em: 02 jun. 2018.

BRASIL. Decreto-lei no 5.452, de 01 de maio de 1943. Diário Oficial da União, Rio de Janeiro, 01 maio 1943. Disponível em: <http://www. planalto.gov.br/ccivil_03/decreto-lei/Del5452.htm\#art2>. Acesso em: 18 maio 2018.

BRASIL. Tribunal Superior do Trabalho. 70 anos CLT. Brasília, [2013]. Disponível em: <http://www.tst.jus.br/web/70-anos-clt/historia>. Acesso em: 31 maio 2018.

BRASIL. Tribunal Superior do Trabalho. Recurso de Revista do Ministério Público do Trabalho. Ação Civil PÚblica. Jornada Móvel e Variável. Invalidade. № RR - 9891900-16.2005.5.09.0004. Relator: Ministro Dora Maria da Costa, 8 ${ }^{\text {a }}$ Turma. Brasília, 23 de fevereiro de 2011. DeJT. Brasilia, 25 fev. 2011. Disponível em:<http://aplicacao5.tst.jus.br/consultaunificada2/inteiroTeor.do?action=printInteiroTeor\&format=html\&highlig $\mathrm{ht}=$ true \&numeroFormatado=RR-9891900-16.2005.5.09.0004\&base $=\mathrm{a}$ cordao\&rowid=AAANGhAA+AAAKi5AAC \&dataPublicacao $=25 / 02 / 201$ $1 \&$ localPublicacao $=$ DEJT \&query $=$ arcos and $>$

CARELLI, Rodrigo de Lacerda. Tempo à disposição é todo tempo à disposição. In: MAIOR, Jorge Luiz Souto; SEVERO, Valdete Souto (Org.).Resistência: aportes teóricos contra o retrocesso trabalhista. São Paulo : Expressão Popular, 2017. p. 267-280.

CASSAR, Vólia Bomfim. Uma das novidades da reforma trabalhista: O contrato intermitente. LTr Suplemento Trabalhista, São Paulo, n. 084/17, p.433-436, 2017. Ano 53. 
CHARÃO, Anderson Pereira; VILlatore, Marco Antônio César. 0 contrato de trabalho intermitente na reforma laboral e os danos ao trabalhador. In: STÜRMER, Gilberto; DORNELES, Leandro do Amaral D. de (Org.). A reforma trabalhista: Na visão acadêmica. Porto Alegre: Verbo Jurídico, 2018. p. 119-131.

CID, Clarissa Felipe. Contrato de Trabalho intermitente e a precarização do direito do trabalho. Revista Fórum Justiça do Trabalho, Belo Horizonte, n. 398, p.57-66, fev. 2017.

COLNAGO, Lorena de Mello Rezende. Trabalho intermitente - trabalho "zero hora" - trabalho fixo descontínuo: a nova legislação e a reforma da reforma. Revista LTr, São Paulo, v. 82, n. 01, p.38-46, jan. 2018. Mensal.

CRUZ, Juliana. Contrato de Trabalho Intermitente. In: GUIMARÃES, Ricardo Pereira de Freitas; MARTINEZ, Luciano. Desafios da reforma trabalhista: De acordo com a MP 808/2017 e com a Lei 13.509/2017. São Paulo: Revistas dos Tribunais, 2017. Cap. 9. p. 149-155.

DELGADO, Maurício Godinho. Curso de Direito do Trabalho. 13. ed. São Paulo: Ltr, 2014.

DELGADO, Maurício Godinho. Direitos fundamentais na relação de trabalho.Revista de Direitos e Garantias Fundamentais, [s.l.], n. 2, p.11-40, 13 ago. 2007. Disponível em:<http://dx.doi.org/10.18759/ rdgf.v0i2.40>. Acesso em: 21 maio 2018.

FERNANDES, Paulo Roberto. A figura do contrato de trabalho intermitente do PL no 6.787/2016 (Reforma Trabalhista) à luz do direito comparado. 2017. Disponível em: <http://ostrabalhistas.com.br/figura-do-contrato-de-trabalho-intermitente-do-pl-no-6- 7872016-reforma-trabalhista-luz-do-direito-comparado/ > . Acesso em 05 nov. 2018.

JORNADA DE DIREITO MATERIAL E PROCESSUAL DO TRABALHO, 2., 2017, Brasília. Enunciados aprovados na $2^{\mathbf{a}}$ Jornada. Brasília: Anamatra, 2017. 1 v. Disponível em: <http://www.jornadanacional.com. br/listagem-enunciados-aprovados-vis1.asp>. Acesso em: 03 jun. 2018.

KONRATH, Angela Maria. O contrato de trabalho intermitente. In: SEVERO, Valdete Souto et al.). Comentário à Lei 13.467/17: contribuições para um enfrentamento crítico. Porto Alegre: HS Editora, 2017. p. 78-81.

LEITE, Carlos Henrique Bezerra. Curso de Direito do Trabalho. 8. ed. São Paulo: Saraiva, 2017. 
LIMA, Francisco Gérson Marques de. Convite ao estudo da hermenêutica em direito do trabalho. São Paulo: CSB, 2017. 32 slides. Disponível em: <http://csb.org.br/wp-content/uploads/2017/11/3578.15_Apostila_Hermeneutica.pdf>. Acesso em: 08 nov. 2018.

MAEDA, Patrícia. Contrato de trabalho Intermitente. In: MAIOR, Jorge Luiz Souto; SEVERO, Valdete Souto (Org.). Resistência: Aportes teóricos contra o retrocesso trabalhista. São Paulo: Expressão Popular, 2017. Cap. 27. p. 317-325.

MAIOR, Jorge Luiz Souto. Trabalho intermitente e golpismo constante. Revista Síntese Trabalhista, São Paulo, n. 334, p.211-215, abr. 2017. Mensal.

NELSON, Rocco Antônio Rangel Rosso. Da flexibilização das relações de trabalho e a consequente violação do mínimo existencial do trabalhador. Revista Espaço Acadêmico, Maringá - Pr, v. 17, n. 200, p.26-36, jan. 2018. Mensal. Disponível em: <http://periodicos.uem.br/ojs/index. php/EspacoAcademico/issue/view/1448>. Acesso em: 21 maio 2018.

NOGUEIRA, Eliana dos Santos Alves. 0 contrato de trabalho intermitente na reforma trabalhista: contraponto com o modelo italiano. In: ESCOLA JUDICIAL DO TRT 15 (Campinas). Revista do Tribunal Regional do Trabalho da 15a Região. 51. ed. Campinas: Escola Judicial do TRT 15, 2017. p. 127-148. Disponível em: <http://portal.trt15.jus.br/web/ biblioteca/revista-do-tribunal>. Acesso em: 21 maio 2018.

NUNES, Rizzatto. 0 Princípio Constitucional da Dignidade da Pessoa Humana: doutrina e jurisprudência. São Paulo: Saraiva, 2002, p. 50.

ORGANIZAÇÃO DAS NAÇÕES UNIDAS (ONU). Declaração Universal dos Direitos Humanos. Assembleia Geral das Nações Unidas em Paris. 10 dez. 1948. Disponível em: <http://www.onu.org.br/img/2014/09/ DUDH.pdf>. Acesso em: 20 maio 2018.

PINHEIRO, Iuri Pereira. Contrato de trabalho Intermitente. In: PINHEIRO, Iuri; MIZIARA, Raphael; GASPAR, Danilo (Org.). Reforma Trabalhista: e os novos Direitos Material e Processual do Trabalho. Porto Alegre: Verbo Jurídico, 2017. p. 185-205.

REIS, Maurício; COSTA, Joana. Jornada de Trabalho parcial no Brasil. Brasília: IPEA: MTPS, 2016. Disponível em: <http://repositorio.ipea. gov.br/bitstream/11058/7314/1/bmt61_jornada.pdf> Acesso em: 13 de nov. de 2018 
RODRIGUEZ, Américo Plá. Princípios de direito do trabalho. 3. ed. São Paulo: Ltr, 2015.

RODRIGUEZ, Américo Plá. Princípios de Direito do Trabalho. São Paulo: LTr, 1993.

SEVERO, Valdete Souto. Contrato de trabalho e trabalho intermitente. In: SEVERO, Valdete Souto et al. Comentário à Lei 13.467/17: contribuições para um enfrentamento crítico. Porto Alegre: Hs Editora, 2017. p. 72-77.

SILVA, Homero Batista Mateus da. Comentários à reforma trabalhista: Análise da lei 13.467/2017 - Artigo por artigo. São Paulo: Revista dos Tribunais Ltda, 2017. Disponível em:<https://www.passeidireto. com/arquivo/38171555/comentarios-a-reforma-trabalhista---homero-batista>. Acesso em: 02 jun. 2018.

TEIXEIRA, Érica Fernandes; GONÇALVES, Nicolle Wagner da Silva. Afrontas ao pacto constitucional: o trabalho intermitente regulamentado e a flagrante afronta aos direitos trabalhistas no Brasil. Revista do Tribunal Regional do Trabalho da $10^{a}$ Região, Brasília, v. 21, n. 2, p.31-42, nov. 2016. Disponível em: <http://revista.trt10.jus.br/index. php/revista10>. Acesso em: 20 maio 2018.

TRADING ECONOMICS. Disponível em: <https://tradingeconomics. com/>. Acesso em: 13 de nov. 2018. 